\title{
The energy cost of exercise
}

\section{By J. V. G. A. Durnin, Institute of Physiology, University of Glasgow, University Avenue, Glasgow $\mathrm{G} \mathbf{2} 8 Q Q$}

There is a regrettable confusion in the minds of many nutritionists about 'exercise' and its differing effects on the body, particularly in the varying relations between the effects of exercise on muscular development, on the efficiency of the cardiovascular system, and on the total levels of energy expenditure. As examples of these interrelations, it is possible to increase muscular development measurably and quite obviously by quite short periods of daily weight lifting. The shoulder and upper arm muscles, for instance, can be augmented in bulk by as little as $5 \mathrm{~min} / \mathrm{d}$ of the appropriate weight-lifting, involving an energy expenditure of perhaps no more than approximately $30-40 \mathrm{~kJ}(7-10 \mathrm{kcal}) / \mathrm{min}$, i.e. a total increase of only approximately $150-200 \mathrm{~kJ}(35-50 \mathrm{kcal})$, a minute proportion of the total daily energy. A second and quite different effect can be produced on the body by say 10 min daily of fast jogging, involving an expenditure of perhaps approximately $40 \mathrm{~kJ}$ (ro kcal)/min. Significant improvement in cardiovascular efficiency can be measured over a period of several weeks of this daily activity in a previously-unfit individual, although again the influence on total daily energy expenditure, approximately $400 \mathrm{~kJ}$ ( $100 \mathrm{kcal}$ ), is virtually negligible. A third form of exercise, different in its effects from these two previous examples, can be illustrated by a game of golf (Scottish type!). Such an activity might last $3 \mathrm{~h}$ and involve an average energy expenditure of say $\mathrm{x} 6 \mathrm{~kJ}(4 \mathrm{kcal}) / \mathrm{min}$ and therefore a total expenditure of about $3 \mathrm{MJ}$ ( $700 \mathrm{kcal}$ ), which is a considerable increment on an average daily energy expenditure, but it will have no influence either on muscular development or on cardiovascular efficiency.

Exercise, therefore, cannot be regarded physiologically or nutritionally in some vague uniform fashion; it is widely varying in its effects and these effects will depend on the particular form of the exercise, on its intensity, and its duration.

These statements appear so self-evident as to be almost unnecessary, but the nutritional literature abounds in misconceptions as to the physiological implications of exercise, and equally the physiological literature frequently demonstrates a misunderstanding of the nutritional aspects. As an illustration of the incomplete understanding of nutritionists in this area of physiology, there is great concern about the prevalence of anaemia in many parts of the world as indicating serious malnutrition. I have no wish to minimize the undesirable aspects of the occurrence of anaemia, but I am sure it helps if it is put in its proper context of what exactly is happening to the human body when it is present. The effect, of course, depends on the degree of the anaemia but it is frequently categorized as being present if men (as opposed to women) have haemoglobin levels of $\mathrm{I}$ ro $\mathrm{g}$ or less/ 1 blood. What exactly are the effects of this on physical function? At the 
normal level of about $\mathrm{I} 50 \mathrm{~g} / \mathrm{l}$, the blood carries approximately $200 \mathrm{ml}$ oxygen $/ \mathrm{l}$. At $110 \mathrm{~g} / \mathrm{l}$, this is reduced to $150 \mathrm{ml} \mathrm{O}_{2} / 1$ blood. Only at very severe levels of physical exertion will this have any real relevance. A level of $150 \mathrm{ml} \mathrm{O}_{2} / 1$ will provide sufficient for very hard physical effort, sufficient for virtually all forms of work and almost all levels of voluntary exercise, except at near extreme levels. In studies which we carried out in New Guinea (Cotes, et al. 1974; Norgan et al. 1974), although their haemoglobin levels were low enough to constitute anaemia, the exercise capacity of the men was in fact higher than that found in well-fed European populations.

Anaemia of this degree, although certainly not a desirable state, has very few physical disadvantages and I am sure a fuller understanding of this area of physiology would assist nutritionists to arrive at more sensible conclusions.

Another area of great confusion, both among nutritionists and medical practitioners, relates to the energy equivalents of gaining and losing weight. Excluding weight gain and loss of fluid which, with the exception of pathological cases, is a fluctuating and temporary phenomenon, the addition of weight to the body requires approximately $40 \mathrm{MJ}(9000-10000 \mathrm{kcal})$ extra for every $\mathrm{kg}$ adipose tissue, and weight loss involves a deficit of about $30 \mathrm{MJ}(7000 \mathrm{kcal})$ for each $\mathrm{kg}$ adipose tissue. Remembering these simple figures would help many people to avoid making either ridiculous or very imprecise statements. For example, to lose $\mathrm{I}$ kg adipose tissue/week requires a negative energy balance of approximately $30 \mathrm{MJ}$ ( $7000 \mathrm{kcal}$ ) over the $7 \mathrm{~d}$, i.e. a deficit of $4.2 \mathrm{MJ}$ (1000 kcal)/d, which is probably an extreme value for anyone to be able to maintain for more than a very short time. Expectations of a weight loss greater than this are unlikely to be fulfilled. Similarly, many people make quite exaggerated or certainly misconstrued statements about the rapidity of weight gain. It would not be uncommon to hear someone talk about a weekend of modest overeating (or overdrinking) where there was a weight gain of $2 \mathrm{~kg}$ or more. Such an addition to the body-weight needs about an extra $80 \mathrm{MJ}$ $(20000 \mathrm{kcal})$. If this occurred during $3 \mathrm{~d}$, the extra intake would be almost $29 \mathrm{MJ}$ $(7000 \mathrm{kcal}) / \mathrm{d}$; i.e. if the normal energy requirement of this person was about ro MJ $(2500 \mathrm{kcal}) / \mathrm{d}$ it would have been necessary to consume about $42 \mathrm{MJ}(10000 \mathrm{kcal}) / \mathrm{d}$ on each of the $3 \mathrm{~d}$, a most improbable state of affairs. A weight gain of this magnitude therefore, on the assumption that it is correct, must include a considerable quantity of fluid, which will be mostly of a very temporary nature.

In order not to be one-sided about this, there are many papers in the exercise physiology literature which contain highly-unlikely values for the energy cost of exercise, energy requirements of weight-lifters of more than $25 \mathrm{MJ}(6000 \mathrm{kcal}) / \mathrm{d}$, for example. An expenditure of $25 \mathrm{MJ}(6000 \mathrm{kcal})$ may be possible on occasional days, but an energy requirement of this amount means that $25 \mathrm{MJ}(6000 \mathrm{kcal})$ is being expended every day. Let us see exactly what this entails.

We might assume that the maintenance requirements of this weight lifter were about $4.2 \mathrm{MJ}(2000 \mathrm{kcal}) / \mathrm{d}$, i.e. excluding the exercise period. Thus, out of the 25 MJ $(6000 \mathrm{kcal})$, I7 MJ (4000 kcal) needs to be expended on the exercise. Weight-lifting training is a very intermittent affair, with a maximum proportion of 
$50 \%$ of the training period being spent on the activity, the other $50 \%$ (usually much more) is for resting, walking slowly around the exercise room, etc. If the actual exercise involves an energy expenditure of about $60 \mathrm{~kJ}(15 \mathrm{kcal}) / \mathrm{min}$, and this would be a very high figure for many of the exercises, the average over the whole training period, including both the exercising and resting times, would therefore be about $33 \mathrm{~kJ}(8 \mathrm{kcal}) / \mathrm{min}$ and expending $\mathrm{I} 7 \mathrm{MJ}(4000 \mathrm{kcal}) / \mathrm{min}$ at this level would take $500 \mathrm{~min}$, or more than $8 \mathrm{~h}$. I venture to suggest that no weight-lifter anywhere spends anything like $8 \mathrm{~h} / \mathrm{d}, 7 \mathrm{~d} /$ week, $365 \mathrm{~d} /$ year on training at this level. In other words, an energy requirement of $25 \mathrm{MJ}(6000 \mathrm{kcal}) / \mathrm{d}$ is probably a gross exaggeration of the true situation.

It is outside the topic of this symposium, but there are equally erroneous statements in the exercise-physiology literature about the protein requirements of exercise.

I should now like to deal briefly with some aspects of the physiology of exercise, an understanding of which I consider is helpful for nutritionists.

Muscular activity is basically of two types, isometric and dynamic, although almost no naturally-occurring exercise is purely the one or the other. However, an approximate example of an isometric exercise is standing still holding a heavy suitcase in each hand. No movement is involved but there may be relatively large-scale muscular activity to maintain the position of the arms and to retain postural control. This activity may cause very large increases in heart rate; indeed it is an activity resulting in considerable cardiovascular stress which is highly undesirable for unfit middle-aged men who should always encourage their wives to carry the cases. There may also be marked local muscular fatigue but, perhaps surprisingly, the energy being expended will not be more than moderate.

Dynamic exercise, such as fast walking, because it is using large-muscle groups, may require much greater expenditures of energy although the heart rate and feeling of fatigue will be much less than with the isometric exercise.

Heart rate is often a very poor indicator of energy expenditure. A good illustration of the lack of relationship is the occasional (I always hope very occasional) extremely-high heart rates which have been recorded in airplane pilots, sometimes as high as I 70 beats/min, during landing or take-off, when they have been sitting in specially-designed seats and been expending, at most, only twice their basal metabolic rate.

The heart rate, as a predictor of energy expenditure, is an index which has been misused by nutritionists. The hypothesis rests on the assumption that by measuring heart rate in an individual, which in practice is not too difficult, an extrapolation can be made to convert this to energy expenditure, the measurement of which in normal every-day life situations can often be extremely difficult. An elementary knowledge of the physiology of the heart would suggest that any relationship between heart rate and energy expenditure must be highly variable.

To explain further, when we undertake some physical activity, the relevant skeletal muscles require more $\mathrm{O}_{2}$ to allow them to contract. Depending on the severity of the exercise and the muscle mass involved, the $\mathrm{O}_{2}$ consumption of the 
whole body can increase from a resting value of about $200-250 \mathrm{ml} / \mathrm{min}$ up to ten or even twenty times that level; in energy units, this means that the resting energy expenditure of about $4 \mathrm{~kJ}(\mathrm{I} \mathrm{kcal}) / \mathrm{min}$ will go up to $40-80 \mathrm{~kJ}(\mathrm{so}-20 \mathrm{kcal}) / \mathrm{min}$.

The muscular component of this total varies. In a $70 \mathrm{~kg}$ man, about half the fat-free mass of the body (or lean body mass) is made up of skeletal muscle, roughly about $30 \mathrm{~kg}$. In the resting state, the $\mathrm{O}_{2}$ requirement of this muscle is about $45 \mathrm{ml} / \mathrm{min}$, or about $20 \%$ of the total requirement of the body. In very-active exercise the skeletal muscles may use up ${ }_{2-4}$ litres $\mathrm{O}_{2} / \mathrm{min}$, i.e. the muscles themselves have increased their $\mathrm{O}_{2}$ consumption by a factor of forty to eighty times. They are enabled to do this by a redistribution of blood in the body, e.g. blood is diverted away from the liver and gut (which, of course, makes the statement one comes across that the increased metabolism resulting from eating a meal is potentiated by exercise something which is most improbable), but the main source of the extra $\mathrm{O}_{2}$ needed by the muscles is provided by a marked increase in the blood flow to the muscles due to a larger cardiac output. The resting cardiac output of about 5 litres/min may go up to 15 or 25 litres/min or even more. The heart will increase its rate of beating, from about $60-70$ beats $/ \mathrm{min}$ at rest up to 180-200 beats/min in severe exercise, but there is also an increase in the volume of blood ejected by the heart at each beat: the resting stroke volume of $70 \mathrm{ml}$ can reach perhaps $120 \mathrm{ml}$.

Therefore a rise in heart rate is only part of the adaptation needed to provide the skeletal muscles with more blood and, unfortunately, at modest levels of physical activity, which is all that most of us ever manage in our daily lives. Heart rate can also be much affected by things such as emotion, temperature, cigarette smoking, drinking tea or coffee, eating, and so on.

In practice, although heart rate and $\mathrm{O}_{2}$ consumption have some sort of a relationship which may be more or less consistent for any particular individual at moderately-severe to very-severe exercise, there is a wide area of mild to moderate physical activity where the relationship is so blurred as to be practically useless.

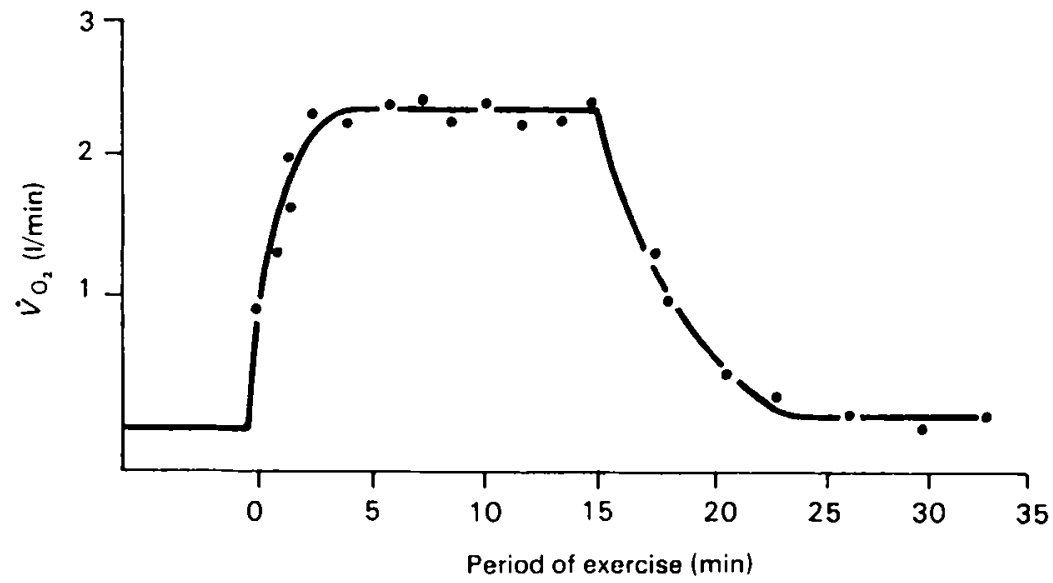

Fig. I. Graphical illustration of the pattern of increase in the oxygen consumption, caused by exercise, during the initial phase, the steady-state and the recovery phase. 
Although we have been discussing the actual $\mathrm{O}_{2}$ consumption or energy requirement of the active skeletal muscles, from the nutritional point of view it is more useful to consider mainly the total energy expenditure of the whole body.

The maximal potential for energy expenditure or, as it is called in exercise physiology terms, the aerobic capacity or exercise capacity or working capacity of an individual, can vary widely. Almost all healthy individuals react in similar ways to exercise of moderate to severe degree (Fig. 1 ). There is an initial period, usually lasting 2-3 min, when heart rate and $\mathrm{O}_{2}$ consumption are adjusting to the needs of the active muscles. During this period the muscles are not receiving enough $\mathrm{O}_{2}$ for their requirements and energy is being supplied anaerobically and from small quantities of stored $\mathrm{O}_{2}$ in the muscles. A so-called $\mathrm{O}_{2}$ debt is being incurred which has to be paid back at the end of the exercise and accounts for the increased heart rate and increased respiratory activity which continues for some minutes after the cessation of exercise.

After this initial period of adjustment, the muscles are being provided with more or less the quantities of $\mathrm{O}_{2}$ they need, and heart rate, cardiac output, and $\mathrm{O}_{2}$ consumption remain fairly stable, unless the exercise is very severe.

When the exercise terminates, there is a gradual return to resting levels which, again depending on the severity of the exercise and the fitness of the individual, usually lasts $10-15 \mathrm{~min}$.

Claims are sometimes made for a long-lasting effect of exercise on the level of energy metabolism so that, it is said, the resting level is not attained for many hours and the metabolic rate remains elevated for $24 \mathrm{~h}$ or more. I find this very hard to accept. There is a very large literature in classical physiology of experiments carried out with meticulous accuracy by some of the most distinguished Scandinavian and American physiologists (Krogh, Christensen, Asmussen, Hansen, Dill, and more recently Ästrand and Saltin) which demonstrate quite clearly that a return to resting levels rarely exceeds 30 min except in prolonged muscular exercise continued to the point of exhaustion. For all other levels of exercise, energy metabolism comes back to the resting level relatively quickly. In any case, the resting baseline level is not an absolute constant, because of slight normal fluctuations, so that it is extremely difficult to be sure that one is really measuring small increases or decreases in metabolic rate. In a study we carried out a few years ago where we were trying to assess the increase in energy metabolism caused by the ingestion of alcohol (Rosenberg \& Durnin, 1978) we became acutely aware of the problems attached to determining a consistent resting baseline and in the end we had to make many repeated measurements and draw a regression line for both the resting state and the state after the intake of alcohol before we could be sure that the lines were significantly different.

To my knowledge, this validation is not usually done when claims for the prolonged effects of exercise are made and I suspect that if any such influence exists it is small and of little importance compared to the immediate effects of the exercise. For example, a moderately-severe level of activity at $42 \mathrm{~kJ}(\mathrm{ro} \mathrm{kcal}) / \mathrm{min}$ lasting for $30 \mathrm{~min}$ involves an expenditure of $1 \cdot 3 \mathrm{MJ}(300 \mathrm{kcal})$. If this exercise 
Table I. Maximal oxygen consumption $\left(\dot{V}_{\mathrm{O}_{2} \max }\right)$ and its relation to the 'stress' of exercise

$\begin{array}{lrrr}\text { Level of exercise ... } & \text { Low } & \text { Moderate } & \text { High } \\ \dot{V}_{\mathrm{O}_{2} \max }(\mathrm{ml} / \mathrm{min}) & 2500 & 3000 & 5000 \\ \text { Energy }(\mathrm{kJ} / \mathrm{min}) & 50 & 63 & 100 \\ \quad(\mathrm{kcal} / \mathrm{min}) & 12 & 15 & 24 \\ \text { Exercise }(\mathrm{kJ} / \mathrm{min}) & & 33 & \\ \quad(\mathrm{kcal} / \mathrm{min}) & & 8 & 30 \\ \text { 'Stress' (as \% of capacity) } & 70 & 50 & \end{array}$

resulted in an increase in the resting metabolism which remained for $\mathrm{I} \mathrm{h}$ and was of the order of $\mathrm{I} \mathrm{kJ}(0.2 \mathrm{kcal}) / \mathrm{min}$, which in fact would be easily measurable, this amounts to $50 \mathrm{~kJ}$ ( $12 \mathrm{kcal}$ ), a small and insignificant quantity, as well as an unlikely one.

However, although the pattern of adaptation to exercise is relatively uniform, the actual levels which are capable of being attained by different individuals have considerable wariability. Some of this variability is in-born, a reflection of our genetic endowment, but it can also be altered by habitual hard physical exercise. Thus, excluding the influence of body size, if we take a population of healthy young men all weighing about $70 \mathrm{~kg}$, the exercise capacity could vary from 2.5 litres $\mathrm{O}_{2}$ consumption $/ \mathrm{min}$ in some individuals to perhaps $5 \mathrm{litres} / \mathrm{min}$ in others. The equivalent values in energy units are from $50 \mathrm{~kJ}(12 \mathrm{kcal}) / \mathrm{min}$ up to $100 \mathrm{~kJ}(24$ $\mathrm{kcal}) / \mathrm{min}$.

There has always seemed to me an obvious relevance for nutritional assessment in these differing capacities. If a man has a maximum capacity to expend energy of $50 \mathrm{~kJ}(12 \mathrm{kcal}) / \mathrm{min}$ and he has work to perform which requires an expenditure of $33 \mathrm{~kJ}(8 \mathrm{kcal}) / \mathrm{min}$ (or if he is playing football at this level), he is exercising at about $70 \%$ of his maximum and he will be much more stressed physically than someone doing the same work whose maximal capacity is perhaps $67 \mathrm{~kJ}$ ( $15 \mathrm{kcal}$ )/min, where the effort constitutes only $50 \%$ of the maximum (Table $\mathrm{I}$ ).

An assessment of exercise capacity is something which may provide very useful information, especially in populations where food availability may be marginally adequate. The information, of course, has its limitations and its importance should not be exaggerated. It indicates mainly cardiovascular and respiratory abilities but nevertheless it is a good general pointer to the level of exercise capacity of the individual which, for that particular person, is important both in relation to work and to active leisure.

The testing of maximal exercise capacity is not difficult. It can be done by exercising the individual to the point of exhaustion, but this, especially in unsophisticated populations in developing countries and even in people being tested in laboratory situations in developed countries, is difficult to do properly and in any case is unnecessary. A series of sub-maximal tests gives equally-valid information. 


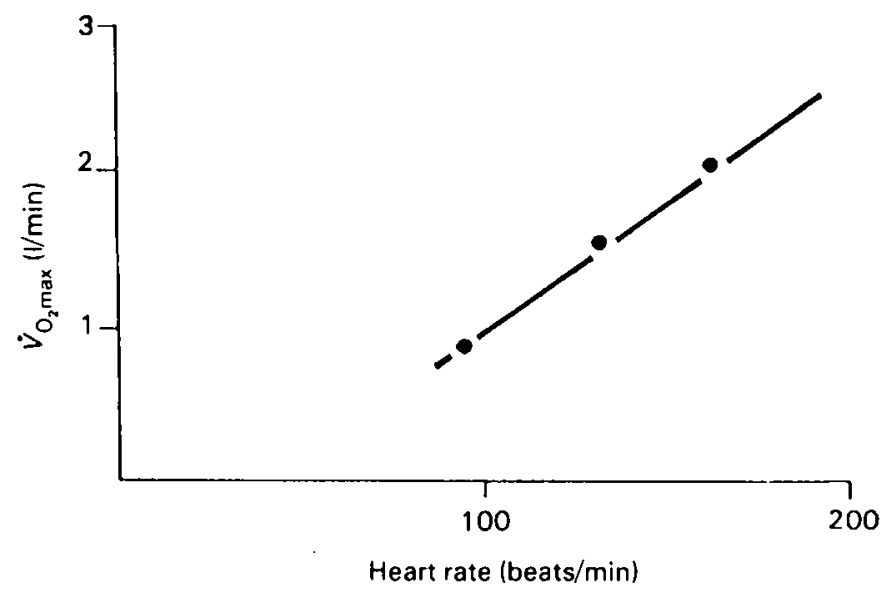

Fig. 2. The prediction of the maximal oxygen consumption $\left(\dot{V}_{\mathrm{O}_{2} \max }\right)$ from measurements made at three different levels of sub-maximal exercise and extrapolated to a theoretical maximum where heart rate would be 195 beats $/ \mathrm{min}$.

These tests can be conducted in quite primitive situations as well as in the laboratory. In a reasonably-equipped laboratory, the test should be done ideally using a treadmill or, failing that, a bicycle ergometer. Heart rate and $\mathrm{O}_{2}$ consumption are measured at three different levels of exercise where the heart rates will be approximately $100 / \mathrm{min}, 130 / \mathrm{min}$, and $160-170 / \mathrm{min}$. In our own laboratory our routine for average young men is to do a $5 \mathrm{~min}$ period of walking at $4.8 \mathrm{~km} / \mathrm{h}(3 \mathrm{miles} / \mathrm{h})$, then to increase the speed to $6.4 \mathrm{~km} / \mathrm{h}(4 \mathrm{miles} / \mathrm{h})$ for a further $5 \mathrm{~min}$, then to do a third $5 \mathrm{~min}$ at $6.4 \mathrm{~km} / \mathrm{h}(4 \mathrm{miles} / \mathrm{h}$ ) at either a $5 \%$ or a 10\% gradient (depending on the fitness of the individual). Heart rate and $\mathrm{O}_{2}$ consumption are measured for $1 \mathrm{~min}$ during the final $2 \mathrm{~min}$ of each $5 \mathrm{~min}$ period (i.e. between $3 \mathrm{~min} 30 \mathrm{~s}$ and $4 \mathrm{~min} 30 \mathrm{~s}$ ), when the individual is in a reasonably 'steady-state'.

The equivalent loads for an average young woman are (I) $4 \mathrm{~km} / \mathrm{h}(2.5 \mathrm{miles} / \mathrm{h})$ on the level, (2) $4.8 \mathrm{~km} / \mathrm{h}(3 \mathrm{miles} / \mathrm{h})$ at a $5 \%$ gradient, (3) $4.8 \mathrm{~km} / \mathrm{h}(3 \mathrm{miles} / \mathrm{h})$ at a $10 \%$ gradient.

The relation between heart rate and $\mathrm{O}_{2}$ consumption is then plotted and the $\mathrm{O}_{2}$ consumption is assessed at a theoretical heart rate of $195 / \mathrm{min}$, by extrapolation (Fig. 2).

There is nothing very complicated about this procedure, and we have validated it against many measurements of testing at actual maximal levels of exercise. With experience, the whole procedure takes less than $0.5 \mathrm{~h}$ and, as an example of the possible scale of such measurements, Mr. Taylor, one of my research assistants, has carried out between 400 and 500 of these during the past 6 months.

If a treadmill is not available or if the test is done in difficult field conditions, a simple step test can be substituted, and indeed we are about to undertake a series 
of these tests on some women living in a rural environment in South India. Using two different blocks of wood to provide steps of $300 \mathrm{~mm}(12 \mathrm{in})$ and $380 \mathrm{~mm}$ ( 5 in), three different levels of exercise can be done with similar heart rates to those of the treadmill test.

Although these measurements cannot easily be done on very large numbers of individuals, by a statistically-acceptable sampling of the population under study, valid and very useful information could be assembled. I have been strongly of the opinion that for far too long nutritionists have relegated themselves to thinking that only very superficial and simple assessments can be made in field situations. I have never accepted this attitude; there is no reason why we cannot behave as good scientists and take our laboratory equipment into the field whenever this is at all possible.

There are two other brief things to say about these exercise tests. First, in order to allow for differing body sizes both within and between populations, maximal $\mathrm{O}_{2}$ consumption $\left(\dot{V}_{\mathrm{O}_{2} \max }\right)$ is usually expressed as $\mathrm{ml} \mathrm{O}_{2} / \mathrm{kg}$ body mass per min. In the example I gave of a group of $70-\mathrm{kg}$ men, those with a $\dot{V}_{\mathrm{O}_{2} \max }$ of $2.5 \mathrm{litres} / \mathrm{min}$ have a capacity of $36 \mathrm{ml} / \mathrm{kg}$ per min, which is relatively low, but common, and those with 5.0 litres $/ \mathrm{min}$ have a capacity of $7 \mathrm{I} \mathrm{ml} / \mathrm{kg}$ per min, which is very high. A value of $40-50 \mathrm{ml} / \mathrm{kg}$ per min would probably reflect values varying from a level which was reasonably acceptable up to quite good.

Second, extrapolation to a heart rate of $195 / \mathrm{min}$ as maximum is valid only for young men and women. For older people, a rough guide is to subtract the age from 220: i.e. a maximum theoretical heart rate for a 40 -year-old man would be $220-40$ ( 180 beats $/ \mathrm{min}$ ). For children or adolescents, who are also appropriate groups for these assessments, an assumption of a maximal heart rate of $200 / \mathrm{min}$ will not introduce significant error.

Finally, some examples of the energy expended in varying situations may be of interest. To simplify comparisons, all the values will apply to a $70 \mathrm{~kg}$ man.

It is probably hardly worth mentioning the effect of the occupation of the individual, first because very little up-to-date information is available and second because the general picture is fairly well known. For a physically-inactive office job or a moderately-active job working as a joiner, or a very active job as a labourer, the requirements for all the various activities of leisure and for sleep will be similar and amount to about $6.7 \mathrm{MJ}(1600 \mathrm{kcal}) / \mathrm{d}$; the work entails an energy expenditure of $4.6 \mathrm{MJ}$ (1 $100 \mathrm{kcal})$, or $5.8 \mathrm{MJ}(1400 \mathrm{kcal})$, or $8.0 \mathrm{MJ}$ (1900 kcal) respectively (Table 2). These are not enormous differences and indeed the difference between

\section{Table 2. Energy expenditure related to occupation}

$\begin{array}{lrr}\text { Occupation... } & \overbrace{\mathrm{kJ} / \mathrm{d}} & \mathrm{kcal} / \mathrm{d} \\ \text { Leisure and sleep } & 6700 & \mathrm{I} 600 \\ \text { Work } & 4600 & \mathrm{I} 100 \\ \text { Total } & 1 \mathrm{I} 300 & 2700\end{array}$

\begin{tabular}{|c|c|}
\hline \multicolumn{2}{|c|}{ Moderately active } \\
\hline $\mathrm{kJ} / \mathrm{d}$ & \\
\hline $\begin{array}{l}6700 \\
5860\end{array}$ & \\
\hline $1255^{\circ}$ & 300 \\
\hline
\end{tabular}

\begin{tabular}{|c|c|}
\hline \multicolumn{2}{|c|}{ Very active } \\
\hline $\mathrm{kJ} / \mathrm{d}$ & $\mathrm{kcal} / \mathrm{d}$ \\
\hline 6700 & 1600 \\
\hline $\begin{array}{r}795^{\circ} \\
14640\end{array}$ & $\begin{array}{l}1900 \\
3500\end{array}$ \\
\hline
\end{tabular}




\section{Table 3. Energy expenditure during recreation}

\begin{tabular}{|c|c|c|c|c|}
\hline & Sedentary & Light & Moderate ${ }^{\bullet}$ & Heavy \\
\hline $\begin{array}{l}\text { Rates for women } \\
(\mathrm{kJ}(\mathrm{kcal}) / \mathrm{min} \\
\text { per } 55 \mathrm{~kg})\end{array}$ & up to $8(2 \cdot 0)$ & $\begin{array}{l}8-16 \\
(2 \cdot 0-4 \cdot 0)\end{array}$ & $\begin{array}{l}16-24 \\
(4 \cdot 0-6 \cdot 0)\end{array}$ & $\begin{array}{l}>24 \\
(>6.0)\end{array}$ \\
\hline \multirow{2}{*}{$\begin{array}{l}\text { Rates for men } \\
(\mathrm{kJ}(\mathrm{kcal}) / \mathrm{min} \\
\operatorname{per} 65 \mathrm{~kg})\end{array}$} & up to ro $(2 \cdot 5)$ & $\begin{array}{l}10-20 \\
(2 \cdot 5-5 \cdot 0)\end{array}$ & $\begin{array}{l}20-30 \\
(5 \cdot 0-7 \cdot 5)\end{array}$ & $\begin{array}{l}>30 \\
(>7.5)\end{array}$ \\
\hline & $\begin{array}{l}\text { Card games } \\
\text { Musical } \\
\text { instruments }\end{array}$ & $\begin{array}{l}\text { Archery } \\
\text { Billiards } \\
\text { Bowls } \\
\text { Cricket } \\
\text { Croquet } \\
\text { Golf } \\
\text { Sailing } \\
\text { Table tennis } \\
\text { Volleyball }\end{array}$ & $\begin{array}{l}\text { Badminton } \\
\text { Canoeing } \\
\text { Cycling } \\
\text { Dancing } \\
\text { Gardening } \\
\text { Gymnastics } \\
\text { Hockey } \\
\text { Horse riding } \\
\text { Jogging } \\
\text { Skiing } \\
\text { Swimming } \\
\text { Tennis } \\
\text { Walking }\end{array}$ & $\begin{array}{l}\text { Athletics } \\
\text { Basketball } \\
\text { Boxing } \\
\text { Climbing } \\
\text { Cross-country } \\
\text { running } \\
\text { Football } \\
\text { Rowing } \\
\text { Squash }\end{array}$ \\
\hline
\end{tabular}

'Many sports in the 'moderate' category may involve a very large range of energy expenditure, from light to very heavy.

the energy expended in a sedentary job and in a very-active job represents only half the combined energy needed for sleep and $8 \mathrm{~h}$ of fairly inactive leisure.

Table 3 gives a general indication of the relative energy outputs necessitated by various sports and recreations. There is, of course, very considerable variability in the way in which an individual can play badminton, or swim, or play football and many sports or recreations involve exercise which can cover the complete range from very light to extremely energetic; swimming and walking are good examples of this; gentle walking on the level can be done with very-modest energy expenditures whereas walking uphill rapidly exerts the body to the extreme.

Perhaps the commonest form of exercise nowadays is jogging. Jogging is pandemic, although I suspect it will not last for very much longer at its present level of popularity. I know well that it is addictive and that even sensible people pretend they enjoy it. The enjoyment is seldom obvious on the faces of the participants while they are actually running. While I very much approve of exercise, I find jogging to be a particularly useless form of activity, with little apparent pleasure to be obtained from it.

However, there may be some interest in knowing the levels of energy expended in jogging. Again these are variable but approximately $40-50 \mathrm{~kJ}(10-12 \mathrm{kcal}) / \mathrm{min}$ will be expended in running at $8-9.6 \mathrm{~km} / \mathrm{h}(5-6$ miles $/ \mathrm{h})$. That is, moderately-fast jogging for $\mathrm{I} h{ }_{5} \mathrm{~d} /$ week will increase the daily output of energy by about $\mathrm{I} \cdot 7 \mathrm{MJ}$ $(400 \mathrm{kcal}) / \mathrm{d}$ over the whole week (Table 4$)$. This is quite a considerable quantity and may well have an effect not only on cardiovascular fitness but also on body 


\section{Table 4. Energy of jogging}

Duration

Speed

Energy

Total increase

Effect as mean increased energy per $d$
$60 \mathrm{~min}, 5 \mathrm{~d} /$ week

$8-9.6 \mathrm{~km} / \mathrm{h}(5-6 \mathrm{miles} / \mathrm{h})$

$40-50 \mathrm{~kJ} / \mathrm{min}(10-12 \mathrm{kcal} / \mathrm{min})$

$2500 \mathrm{~kJ}$ or $12550 \mathrm{~kJ} /$ week (600 kcal or $3000 \mathrm{kcal} /$ week)

I $700 \mathrm{~kJ}(400 \mathrm{kcal})$

composition; it may often be sufficient to increase the muscle mass of the legs and to decrease the total fat mass of the body.

An even more reprehensible activity than jogging is actually running a marathon. Surely no sane, well-balanced person would undertake such a thing other than as a punishment for serious failings in other aspects of lifel However, for those who manage to complete the 26 miles and whatever yards, there can be some satisfaction in that they have expended an extra $12.6 \mathrm{MJ}(3000 \mathrm{kcal})$. The actual speed at which they run the marathon and the time they take to complete the distance have relatively little effect on the total amount of extra energy.

I hope I have perhaps put some aspects of the energy cost of exercise into a more balanced and knowledgeable perspective. It is an area of some importance for nutritionists and can influence many different facets of life. For instance, encouraging the elderly to do regular exercise, such as walking, not only makes them feel better but also, because of the increase in energy output and therefore a better appetite and larger food intake, makes them less likely to suffer from nutrient deficiencies.

The effect of physical activity on energy expenditure, and therefore on energy requirements, as well as on the overall quality of life, is a most important area of nutrition and I believe that it is a duty of nutritionists to understand well its basic physiology.

\section{REFERENCES}

Cotes, J. E., Anderson, H. R. \& Patrick, J. M. (1974). Philosophical Transactions, Royal Society London B 268, 349-361.

Norgan, N. G., Ferro-Luzzi, A. \& Durnin, J. V. G. A. (1974). Philosophical Transactions, Royal Society London B268, 309-348.

Rosenberg, K. \& Durnin J. V. G. A. (1978). British fournal of Nutrition 40, 293-298. 